\title{
Dr. William J. McIlroy MD, FRCP(C)-June 7, 1932-March 7, 2016
}

Dr. McIlroy was a senior neurologist at the Toronto Western Hospital, where he had spent his career. Bill grew up in South Kingsway in Etobicoke, where he was a champion swimmer coached by the legendary Gus Ryder. He was Head Boy at the University of Toronto Schools and then graduated in medicine from the University of Toronto in 1956. His training in neurology was at Toronto under J. C. Richardson, the Massachusetts General Hospital under Raymond Adams and at the National Hospital, Queen Square, London. He obtained a Fellowship from the Royal College of Canada in 1963 and was recruited to the Toronto Western Hospital.

Bill was the consummate neurologic consultant. On his appointment he was bequeathed antique furniture, including the examining table of the retiring Physician-in-Chief, Dr. Wilbert Hurst Brown. This he maintained till retirement, although in later years it was compressed into the standard corporate-issue cubicle. He was highly organized, recording his notes in a large sinistral script and always leaving a clean desktop at the end of the day. $\mathrm{He}$ fully exemplified the "Three A's," his own version of the Royal College "CanMeds" roles, namely Availability, Ability and Affability.

To this must be added an administrative capacity that was frequently sought. On the retirement of Jack Silversides in 1971 Bill became Head of the Division of Neurology at the Toronto Western Hospital, continuing in that role until 1988. At the same time he was Director of the Neurology Training program at the University of Toronto. He was Senior Vice-President of Medical
Affairs and Education at the combined Toronto General and Toronto Western Hospitals from 1990 to 1993. From 1982 to 2008 he was Medical Advisor to the Multiple Sclerosis Society of Canada, and from 1989 to 1995 he chaired the Medical Advisory Board of the International Federation of Multiple Sclerosis Societies. Bill's most enduring administrative contribution was in the concentration and development of basic and clinical neuroscience programs at the Toronto Western Hospital. From 1985 to 1988 he was the first Director of the Combined Neuroscience Program.

Bill was an excellent clinical teacher, engaging students with humorous and often self-effacing anecdotesmany derived from his own training experiences-to emphasize and embed neurologic doctrine.

In his early years Bill greatly enjoyed the Ontario Lake country. He was an avid reader and enjoyed travel with his wife Ellen, a senior docent with the Art Gallery of Ontario. They are survived by four accomplished offspring.

\section{DisClosures}

John Wherrett does not have anything to disclose.

John Wherrett
Department of Medicine, University of Toronto, Toronto,
Ontario, Canada

